\title{
Dwindling status of Epimedium elatum (Morren \& Decne) and its geographical distribution in Kashmir Himalaya, India
}

\author{
Sajad Ahmad Lone ${ }^{1,2}$, Saleem Mushtaq², Qazi Parvaiz Hassan²,4*, \\ Suphla Gupta3,4
}

'Department of Botany, Govt College for Women, Nawakadal, Srinagar, J\&K, 190002, India, ${ }^{2}$ Biotechnology division, CSIR-Indian Institute of Integrative Medicine, Sanatnagar, 190005, India, ${ }^{3}$ Plant Biotechnology division, CSIR-Indian Institute of Integrative Medicine, Jammu-180001, India, ${ }^{4}$ Academy of Scientific and Innovative Research (AcSIR), Anusandhan Bhawan, New Delhi, 110001, India

Received: September 10, 2017 Accepted: November 28, 2017 Published: January 06, 2018

\section{*Corresponding Authors:} Parvaiz Qazi,

Biotechnology division, CSIRIndian Institute of Integrative Medicine, Sanatnagar, 190005 India

Email Id: qphassan@iiim.ac.in Sajad Ahmad Lone, Department of Botany, Govt College for Women, Nawakadal, Srinagar, J\&K, 190002, India

Email Id: Sjdlone46@gmail.com KEYWORDS: Icariin, aphrodisiac, kashmir himalayas, conservation, endangered species.

\section{ABSTRACT}

Epimedium elatum (Morren \& Decne) of family Berberidaceace is a rare perennial medicinal plant, endemic to high altitude forests of Northwestern Himalayas in India. Ethnobotanically, it has been used as an ingredient for treatment of bonejoint disorders, impotence and kidney disorders in Kashmir Himalayas. Phytochemically, it is rich in Epimedin ABC and Icariin; all of these have been demonstrated to possess remarkable biological activities like PDE-5 inhibition (treatment of erectile dysfunction), anticancer, antiosteoporosis antioxidant and antiviral properties. The present investigation reports its traditional usage, comprehensive distribution and conservation status from twenty ecogeographical regions in Kashmir Himalayas, India. The species was reported from Gurez valley for the first time. Numerous threats like excessive grazing, deforestration, habitat fragmentation, tourism encroachment, landslides and excessive exploitation have decreased its natural populations in most of the surveyed habitats. Consequently, its existence may become threatened in near future if timely conservation steps are not taken immediately by concerned stakeholders involved in medicinal plant research. Moreover, use of plant tissue culture techniques is recommended for development of its in vitro propagation protocols. Therefore, introduction of this medicinal plant in botanical gardens, protected sites and development of monitoring programmes are needed for its immediate conservation in Northwestern Himalayas, India.

\section{INTRODUCTION}

Northwestern Himalayas in India is one of the hotspots of biodiversity due to extensive variation in land-scapes, ecoedaphic conditions, forest types and climatic conditions [1]. It has a rich variety of medicinal \& aromatic plants (1748), known globally for their ethnobotany, phytochemical diversity, and pharmacological properties [2]. Unfortunately, continuous exploitation from the wild has depleted their natural populations over the years due to unending demand from industry and local markets [3]. Most of endemic medicinal plants are now facing risk of extinction in their native habitats [1,4 and 5]. To initiate conservation arrangements for such endangered species, there is urgent need to identify their declining populations in different geographical areas [6]. During last few decades, many medicinal plants have been categorized either as vulnerable, threatened or critically endangered in Kashmir Himalayas like Podophyllum hexandrum, Picrorhiza kurroa, Aconitum heterophyllum,
Rheum emodi, Arnebia benthami, Mecanopsis aculeate, Trillium govanianum [5,7 and 8]. Therefore, there is vital need to assess declining populations of these key medicinal plants of Kashmir Himalayas in India.

Epimedium elatum (Morren \& Decne) is one such medicinal plant of Kashmir valley facing very high extinction risk. It is a medicinal herb (Fig.1), endemic to shady thick forests in India and Pakistan [9-15]. The plant has representative 'three branches and nine leaves' morphology in Himalayas, a character universal to all Epimedium species. Traditionally, it has been used in treating many ailments of bone and joint disorders [12]. It contains a high content of key phytochemicals like epimedin B \& C, icariin, and icariside-I [11-13 and 16] Pharmacologically, extracts or chemical components from E.elatum have been assessed for their antimicrobial [10 and 11], antioxidant [11 and 16] and PPAR- $\gamma$ (peroxisome proliferatoractivated receptor-gamma) ligand-binding activities [10]. A perusal of literature indicates that Kashmir Himalayan

Copyright: $\odot 2018$ The authors. This article is open access and licensed under the terms of the Creative Commons Attribution License (http://creativecommons.org/licenses/by/4.0/) which permits unrestricted, use, distribution and reproduction in any medium, or format for any purpose, even commercially provided the work is properly cited. Attribution - You must give appropriate credit, provide a link to the license, and indicate if changes were made. 
region has witnessed depletion of its endemic medicinal flora due to overharvesting, overgrazing, illegal trade and other anthropogenic pressures [6, 8 and 17]. As such, occurrence of E.elatum may turn into threatened (IUCN category) in near future if appropriate conservation strides are not taken instantaneously. Incidentally, a study was needed to identify its declining populations in different regions of Kashmir Himalayas for developing quick conservation strategies. Therefore, present investigation attempted to provide dwindling status and extended distribution of E.elatum, along with its traditional usage prevalent in Kashmir Himalayas for the concerned stakeholders involved in medicinal plant research in India. The foremost aim of the study was to focus on therapeutic potential of E.elatum and need for its conservation to preserve its natural germplasm from getting extinct in Northwestern Himalayas in India.

\section{MATERIAL AND METHOD}

\section{Study Area}

The study area comprises of pleasant and sub-alpine regions between $33^{\circ} 20-34^{\circ} 54^{\prime} \mathrm{N}$ latitudes and $73^{\circ} 55^{\prime}-75^{\circ} 3^{\prime} \mathrm{E}$ longitudes in the Northwestern Himalayas in India (Fig.2). Information on its taxonomy and distribution was documented by reviewing the pertinent literature and scrutinizing herbarium sheets at University of Kashmir, Hazratbal, Srinagar J\&K. Extensive exploration was made between June to September of 2013-2015 (flowering \& fruiting time) based on reported localities (herbarium archives, written floras, research papers and internet search engines). Multiple parameters were recorded such as no of populations in $1 \mathrm{~km}^{2}$ area, herbivory and vulnerability score (0-3), and area of occupancy (Table 1). The plants were identified by taxonomists and the herbarium specimens were deposited respectively in Herbarium of University of Kashmir (KASH), Hazratbal, Srinagar and CSIRIndian Institute of Integrative Medicine (CSIR-IIIM Jammu, J\&K, India [14 and 15].

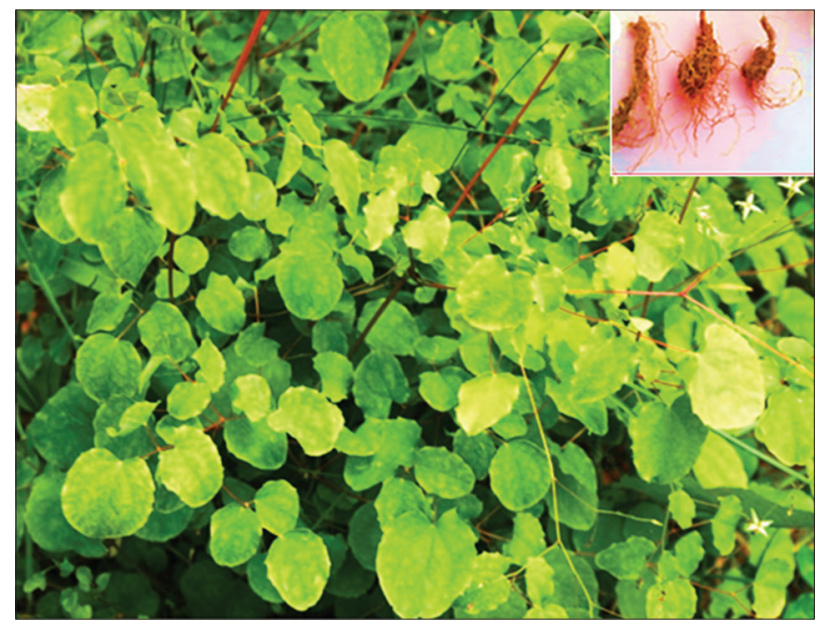

Figure 1: E.elatum (Morr \& Decne) of Berberidaceae family is shown here growing under cultivation at Yarikhah field station, CSIR-IIIM Jammu. Both underground \& aerial parts are used for ethnomedicinal purposes

\section{Ethnobotanical Surveys}

Ethnobotanical data was collected between summer of 2013 and 2015 following a standard operating procedure. Questionnaire was prepared and elderly Hakeem's of the particular tribal community (Gujjar \& Bakkarwals) were interviewed. In addition, the specimen plant was shown to them \& they mentioned its uses and same were properly documented.

\section{RESULTS \& DISCUSSION}

\section{Traditional usage of E.elatum in Kashmir Himalayas}

In the present investigation, we surveyed different geographical areas in Kashmir Himalayas to verify its ethnomedicinal usage. Dried powder from aerial and rhizome parts (Fig.1) was used alone or in mixture with other medicinal extracts for health management of erectile dysfunction, body weakness, increasing body stamina, treating kidney disorders, and bonejoint disorders. Ethnobotanical surveys in the Northwestern Himalayas of Kashmir forests revealed that E.elatum has been used traditionally as an ingredient in many medicines to treat cold related cough, severe running nose, toothache, tooth-decay, bones and joints diseases [12]. E.elatum was found to be an important component of various secret winter herbal teas and tonics, used by tribal communities in forests of Jammu and Kashmir. Its ethnomedicinal usage for treatment of bone related disorders was also confirmed after consulting local Hakeem's in Gurez valley. Fresh aerial parts of E.elatum are harvested in large numbers from high altitudes and used as cattle fodder. Particularly, goats were found to have a special liking for this plant during grazing, confirming its name "horny goat weed". However, we found certain local Gujjar and Bakkarwal communities quite reluctant to share its traditional usage in areas like Yusmarg, Gulmarg and Aru (Pahalgam) regions of Jammu and Kashmir, India.

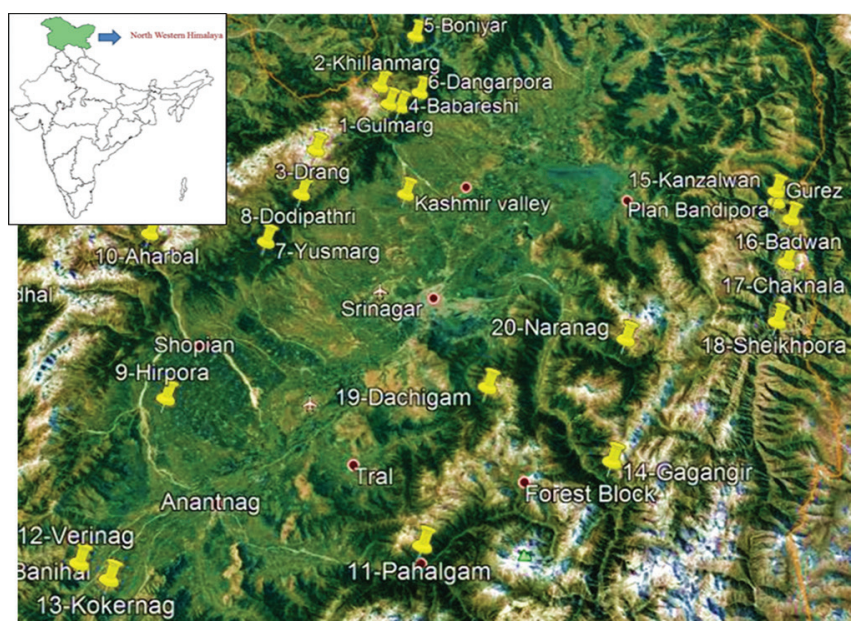

Figure 2: Distributional map of E.elatum (Morr \& Decne) in Northwestern Himalayas, India. The plant was collected from twenty ecozones in Kashmir Himalayas, which are shown here in the Google Earth map from serial no 1-20 
Table 1: Location, availability, ecological features and vulnerability-herbivory score for E pi medi um el atum. In last category, each parameter was subjectively rated from 0 (not vulnerable) to 3 (highly vulnerable). *A00-Area of occupancy

\begin{tabular}{|c|c|c|c|c|c|c|c|c|c|}
\hline Site & Locality or region & Code & Climate zone & Aspect & Altitude & No of populations $\left(1 \mathrm{~km}^{2}\right)$ & Vulnerability score & Herbivory score & ${ }^{*} \mathrm{~A} 00 \mathrm{Km}^{2}$ \\
\hline Gulmarg & Gulmarg Baramulla & $G L$ & Alpine & NW & 2725 & $30-38$ & 0 & 0 & 6 \\
\hline Baba reshi & Tangmarg Baramulla & $\mathrm{BR}$ & Sub-alpine & NW & 2694 & $10-16$ & 2 & 2 & 4 \\
\hline Drang & Tangmarg Baramulla & DR & Sub-alpine & NW & 2301 & $3-6$ & 3 & 3 & 4 \\
\hline Dangarpora & Sheeri Baramulla & $D G$ & Alpine & NW & 2592 & $2-6$ & 3 & 3 & $1-2$ \\
\hline Boniyar & Uri Baramulla & BY & Sub-alpine & NW & 2148 & $4-10$ & 2 & 2 & 3 \\
\hline Yusmarg & Yusmarg Budgam & YS & Sub-alpine & NW & 2383 & $2-6$ & 3 & 3 & 2 \\
\hline Dodipathri & Dodipathri Budgam & $\mathrm{DP}$ & Alpine & NW & 2432 & $13-15$ & 2 & 3 & 4 \\
\hline Naranag & Naranag Ganderbal & NAR & Sub-alpine & $N E$ & 2272 & $20-33$ & 0 & 0 & 4 \\
\hline Gagangir & Gagangir Ganderbal & $G G$ & Sub-alpine & NE & 2435 & $3-6$ & 3 & 3 & 2 \\
\hline Dachigam & Harwan Srinagar & DGM & Sub-alpine & SE & 2912 & $12-16$ & 0 & 0 & $6-10$ \\
\hline Pahalgam & Pahalgam Anantnag & PGM & Alpine & SE & 2206 & $3-6$ & 3 & 3 & 2 \\
\hline Kokernag & Kokernag Anantnag & KNG & Sub-alpine & SE & 2343 & $3-6$ & 2 & 3 & 2 \\
\hline Verinag & Verinag Anantnag & VNG & Alpine & NW & 1935 & $8-10$ & 2 & 2 & 2 \\
\hline Khillanmarg & Gulmarg Baramulla & KMG & Sub-alpine & NE & 3133 & $12-15$ & 3 & 3 & 4 \\
\hline Chaknala & Gurez Bandipora & CNG & Sub-alpine & NE & 2508 & $2-6$ & 3 & 3 & 1 \\
\hline Sheikhpora & Gurez Bandipora & $S P G$ & Sub-alpine & NE & 2646 & $14-17$ & 1 & 1 & 4 \\
\hline Badwan & Gurez Bandipora & $B D G$ & Sub-alpine & NE & 2431 & 6-8 & 2 & 2 & 2 \\
\hline Kanzalwan & Gurez Bandipora & $K Z G$ & Sub-alpine & SE & 2521 & $9-12$ & 2 & 2 & 2 \\
\hline Hirpora & Hirpora Shopian & $\mathrm{HP}$ & Alpine & SE & 1818 & 1 & 3 & 3 & 1 \\
\hline Aharbal & Aharbal Kulgam & $A B$ & Sub-alpine & NE & 2425 & $25-39$ & 0 & 0 & $4-10$ \\
\hline
\end{tabular}

Therefore, more ethnobotanical surveys with some economic incentives for these tribal communities are necessary to explore its secretive traditional usage prevalent in Kashmir Himalayas. These surveys can enrich its chances of becoming a potent therapeutic medicinal herb in India. Research can play an important role to explore its medicinal potential, and develop quick conservation strategies. Thus, more research efforts are needed from concerned stakeholders involved in medicinal plant exploration in India.

Interestingly, ethnopharmacological use of Epimedium species is well written and properly documented in certain Traditional Chinese Medicine (TCM) books like 'Chinese Materia Medica' [18]. The aphrodisiac property (sexual tonic) of these medicinal plants was revealed accidently by a Shepherd (goat herder) who noticed far more sexual activity in his goats on eating these plants in some Chinese village [18]. That is why these plants are commonly known as horny goat weeds in China. They have been used for treatment of erectile dysfunction from last two thousand years in China, Japan, and Korea [18]. Pharmacopoeia Commission of China (2010) [19] has reported several biological effects to Herba Epimedii like reinforcing the kidney, bones, limbs, coldness, muscle contracture, and hypertension [18]. Many marketable products containing Herba Epimedii ingredients are sold as 'health supplements' due to their sex enhancing effects [18]. Notable species like E.sagittatum, E.grandiflorum E.koreanum, E. myrianthum, E.acuminatum and E.leptorrhizum are used traditionally to treat impotence, spermatorrhoea, osteoporosis, menopause disorder, rheumatic arthritis and chronic tracheitis [18, 20-22].

Previously, there was no ethnomedicinal evidence for E.elatum in the Northwest Himalayas in India. But, local researchers are now keen to document its ethnobotany, phytochemistry, cytogenetics etc [11-16]. More ethnobotanical surveys should be done in Kashmir Himalayas for documenting its traditional usage for future medicinal effectiveness in Indian system of medicine.

\section{Conservational Status in Kashmir Himalayas}

Medicinal plants in Kashmir Himalayas are facing conservational threats due to years of ruthless overexploitation and excessive demand from national and international markets [ 1 and 5]. Agrotechnology of $>1 \%$ and propagation protocols of only $>10 \%$ medicinal plant species is available globally [23]. That is why; most of the medicinal plants are facing extinction risks due to lack of such regeneration mechanisms. During the botanical surveys, it was evident that E.elatum is a rare medicinal plant with little population size in surveyed habitats (Table 1). Its low number of populations and restricted distribution in particular pockets reflects critically rare status. We could not locate its mature individuals in 10 locations in Northwestern Himalayas in India (Table 2). In some habitats like Aharbal, Gulmarg, Dachigam, and Naranag, healthy plant accessions with normal stem height (3-4 feet) were observed, all protected by dense vegetation (temperate coniferous forests), deep shade, and cool moist environment. Nevertheless, in other habitats, overgrazing was the most severe factor affecting its natural populations in YS-DP, DG-DR, HP, PGM-KNG and GG forest ranges of Kashmir valley (Fig.3). Vulnerability scores from 0 (Low) to 3 (High) and area of occupancy $\left(1 \mathrm{~km}^{2}\right)$ for all twenty accessions is specified in Table 1.

In most of these habitats, population size of E.elatum was small, consisting of 5-10 or in some rare cases, 2-3 mature individuals. The average stem height of these accessions ranged from 10$45 \mathrm{~cm}$, that too under the protection of thorny bushes, which are inaccessible to grazing animals in high altitude J\&K forests. This medicinal plant was found in the isolated rock crevices at difficult mountain terrains. It has survived only in certain pockets of these habitats (forests), and hence needs immediate conservation. The dwarf character in the Epimedium species is induced by open sunny conditions or under the influence of partial shade [24]. We also observed short stem height (dwarf character) in the E.elatum germplasm transplanted 
at CSIR-IIIM (J\&K) field stations. Quan et al., (2011) reported similar findings in E.wushanense and E.pubescens under wild and cultivated conditions. Epimedium species have been exploited for medicinal purposes in China from last 4 decades, due to which, some are now categorized as vulnerable or endangered according to their recent IUCN Red List categorization [25 and 26]. Therefore, immediate research efforts are needed to assess detailed conservational status of E.elatum in Indian Himalayas.

As per the ecological field observations, E.elatum performs better on a northwest shady slope, offering a desired microsite for its greater densities. In view of species performance across the populations, GL, NAR, DGM \& AB were found best naturally adapted populations due to their high population size (Table 1). In view of the high disturbance to its natural habitat, the species might get extinct from wild (YS-DP, DG-DR, HP, PGM-KNG and GG forest ranges) in Kashmir Himalayas in India. Therefore, the introduction of this medicinal plant in botanical gardens, protected sites, and development of monitoring programmes are needed for its immediate conservation by concerned stakeholders involved in medicinal plant research in India.

\section{Occurrence and Extension of Distribution in Kashmir Himalayas}

Recent literature reports that Epimedium species are scattered mainly in different provinces of China and is considered their modern center of diversity and differentiation [18]. They are represented sparsely in Caucasian mountain forests, Alps in Europe and certain far away regions of Northern Africa [27 and 28]. E.elatum is the monotypic plant species of Epimedium genus in Northwestern Himalayas of India and Pakistan. In latter, its distribution is almost unknown, but has been witnessed in the Pallas valley, Utror-Gabral valleys and district Swat of Pakistan [29-31]. In Jammu and Kashmir, E.elatum was reported to be growing only in three ecozones of Kashmir valley like Pahalgam, Gulmarg and Harwan [32 and 33]. During our thorough investigation, we reported its presence in 8 districts in Kashmir province (Table 1). Herbarium specimens of Podophyllum hexandrum deposited at Kashmir University herbarium proved advantageous in finding possible areas for screening distributional availability of this prized but unexplored medicinal plant. Most of its natural populations are facing severe threats such as grazing, excessive harvesting, habitat fragmentation and small population size (Fig.3). Hence, species needs immediate conservation to preserve its existing natural germplasm from further deterioration.

Experimentally, it has been proved that species with specific habitat requirements and restricted distribution have much larger possibilities of extinction than species with a wide habitat range [34]. Research has reported that specificity of the microhabitat frequently becomes a limiting factor in dispersal and availability of rare medicinal herbs [3]. To withstand local climatic conditions, endemic plants often occupy rocky cliffs and drier habitats in Indian Himalayas [3, 5, 35 \& 36]. For the
Table 2: Locations surveyed for E pi medium elatum where its occurrence was not observed after surveying $2-8 \mathrm{~km}^{2}$

\begin{tabular}{lllllc}
\hline Site & $\begin{array}{l}\text { Locality or } \\
\text { region }\end{array}$ & $\begin{array}{c}\text { Code } \\
\text { zone }\end{array}$ & $\begin{array}{l}\text { Climate } \\
\text { zonect }\end{array}$ & $\begin{array}{c}\text { Surveyed area } \\
\left(\mathrm{km}^{2}\right)\end{array}$ \\
\hline Chandanwari & Pahalgam & CDW & Alpine & SW & $5 \mathrm{~km}$ \\
Aru & Pahalgam & AU & Subalpine & SW & $4-8$ \\
Tangmarg & Baramulla & TMG & Subalpine & NW & $4-10$ \\
Lower Munda & Qazigund & LM & Subalpine & NW & $2-4$ \\
Jawarhar Tunnel & Qazigund & JT & Alpine & NW & $2-3$ \\
Dawar forests & Gurez & DWR & Subalpine & NW & $2-4$ \\
Sonmarg & Ganderbal & SMG & Subalpine & NW & $3-7$ \\
Kangan forests & Ganderbal & KGN & Subalpine & NW & $2-4$ \\
Nilnag & Yusmarg & NAG & Subalpine & NE & $2-6$ \\
Doodganga & Yusmarg & DGG & Subalpine & NE & $2-4$ \\
\hline
\end{tabular}

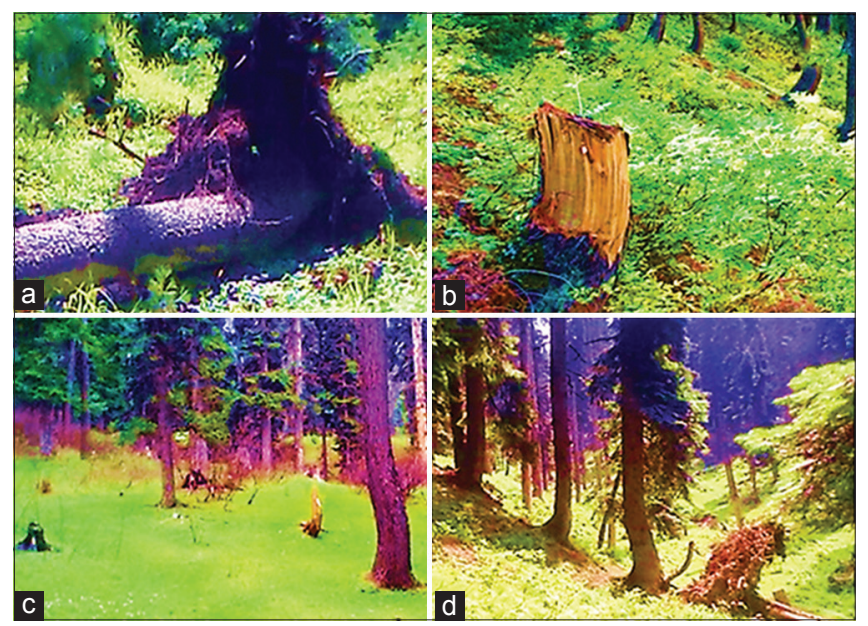

Figure 3: Anthropogenic factors such as grazing and habitat fragmentation affecting natural populations of E.elatum (a)-DangarporaSheeri Baramulla forest; (b)- Sheikhpora-Gurez Bandipora forests; (c)-Drang-Tangmarg forests; (d)-Yusmarg-Budgam forests

long-term viability of rare and endangered species, a minimum population size is necessary [ 37 and 38]. Our research efforts have proved that E.elatum is facing extremely severe threats in Kashmir Himalayas. Therefore, medicinal plant needs immediate captive cultivation. Research has proven that plants produce higher levels of active components when grown within their suitable agro-climatic environment [3]. E.elatum also produces higher content of key bioactive markers such as Epimedin ABC and Icariin [11 and 14]. Therefore, efforts are needed to promote it as a potential medicinal herb for the future in the Indian Himalayas.

\section{Associated Species}

All populations of this medicinal plant were found growing under the forest canopy of Abies and Pinus. Most associated species were identified by taxonomists as Pinus wallichiana, Abies pindrow, Parrotiopsis jacquemontiana, Sambucus wightiana, Aconitum heterophyllum, Viburnum erubescens, Inula racemosa, Picrorhiza kurrooa, Podophyllum hexandrum, Trillium govananium, Thalictrum foliolosum, Aquilegia fragrens, Dioscorea deltiodea, Viburnum grandiflorum, Berberis lyceum \& Rumex nepalensis. Among most of these associated species, 


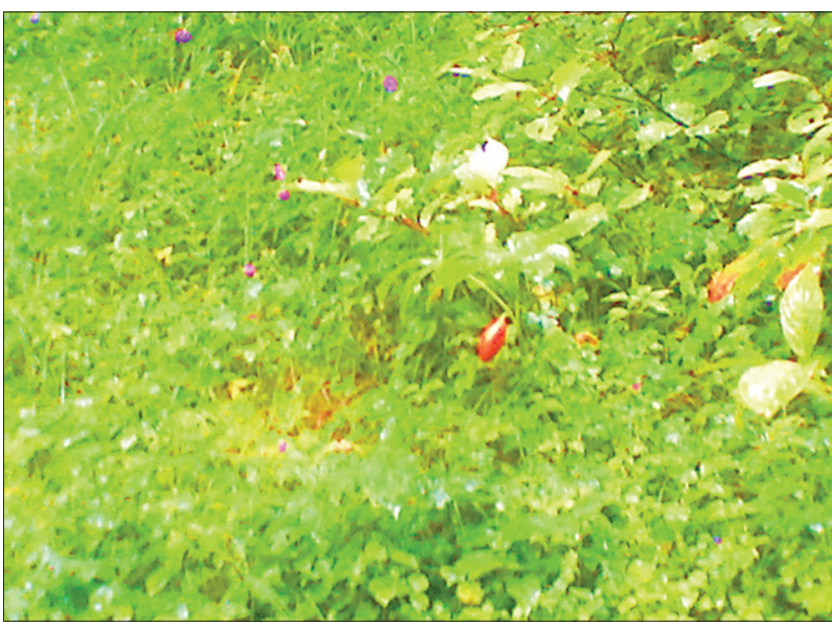

Figure 4: Podophyllum hexandrum and E.elatum growing together in Gulmarg. Both were mostly seen commonly associated species during the study

Podophyllum hexandrum was found to be the common partner of E.elatum in most habitats like PGM, DGM, NAR, KNG, VNG, GL, GG and Gurez except Checknala (Fig.4).

\section{Phenology}

Epimedium plants are known to prefer shade for production of maximum aerial herbage and thick underground rhizome [18 \& 24]. A wide phenotypical difference was observed in E.elatum populations due to a variety of climate, topography and varied ecological habitats in Kashmir Himalayas. Flowering and fruiting time were shown to vary in E.elatum populations across high to low altitude areas in Kashmir valley [14\&15]. At lower altitudes such as Dachigam National park (Srinagar) and Verinag forests, it was found to flower in the month of April, whereas at higher altitudes, such as Khillanmarg (Gulmarg), Sheikhpora (Gurez), Dangarpora (Sheeri Baramulla), it flowered in the months of June to July. The main reasons attributed to these phenological differences could be altitude, the moisture of the habitat, temperature and amount of shade. Therefore, efforts are needed to investigate the detailed phenology of this medicinal plant for understanding its breeding behavior, adaptation biology in Northwestern Himalayas, India.

\section{CONCLUSION}

Most of the key medicinal plants of Indian Himalayas [such as Podophyllum hexandrum \& Trillium govanianum] are facing severe conservational threats. Therefore, collection of ethnomedicinal knowledge of these key medicinal plants is important for their conservation assessment and similarly, their large scale propagation is needed for their commercial usage by industrialists, pharmacologists, botanists and phytochemists. The present data on ethnomedicinal usage of E.elatum along with its availability status in Kashmir Himalayas will aid in proper collection of its ethnobotany, extend its distribution in India and help in designing immediate conservation strategies. Few elite populations of E.elatum (GL, NAR, AB, BR \& DGM) can be used for its bulk propagation, and for enhancing its pharmaceutical value in India. However, for becoming all-important medicinal herb of Indian Himalayas, a number of further studies are required for its quality control studies. More ecological surveys are required to assess its overall distributional range, ethnomedicinal usage and IUCN Redlist status in the Himalayas. Plant tissue culture protocols should be developed to revive this medicinal plant and attempts should be made to produce its secondary metabolites in vitro for their better pharmaceutical usage, thereby reducing demand on wild populations. More studies are required at various levels; assessing its endangered status, ecological behavior, reproductive biology, regional and local distribution patterns, in-situ harvesting pressure and the development of effective agro-technology.

\section{ACKNOWLEDGMENTS}

The authors are thankful to Director CSIR-IIIM, Jammu for providing necessary facilities and support to carry out the ecogeographical surveys. The first author extends acknowledgments to University Grants Commission (UGC), New Delhi for providing fellowship and AcSIR cell of CSIRIIIM for academic support. Beside, we thank local Gujjar \& Bakkarwal elders in Gurez valley and in other areas as well for their cooperation in sharing traditional knowledge.

\section{REFERENCES}

1. Kala CP, Dhyani PP, Sajwan, BS. Developing the medicinal plants sector in northern India: challenges and opportunities. Journal of Ethnobiology and Ethnomedicine. 2006; 2(1):32.

2. Joshi RK, Satyal P, Setzer WN. Himalayan aromatic medicinal plants: a review of their ethnopharmacology, volatile phytochemistry, and biological activities. Medicines. 2016; 3(1):6.

3. Badola HK, Aitken S. The Himalayas of India: A treasury of medicinal plants under siege. Biodiversity. 2003; 4(3):3-13.

4. Dar AR. Studies on some endangered endemic angiosperms of Kashmir Himalaya: Demography in relation to their reproductive biology. Ph.D thesis to University of Kashmir; 2008.

5. Tali BA, Ganie AH, Nawchoo IA, Wani AA, Reshi ZA. Assessment of threat status of selected endemic medicinal plants using IUCN regional guidelines: A case study from Kashmir Himalaya. Journal for Nature Conservation. 2015; 23:80-89.

6. Ganie AH, Tali BA. Vanishing medicinal plants of Kashmir Himalaya, India's Endangered. Available from: http://indiasendangered. com/vanishing-medicinal-plants-of-kashmir-himalaya/. 2013. [Last accessed on 2018, October 17].

7. Sharma DK. Review on traditional medicinal plant Trillium govanianum (Nagchatri). Journal of medicinal plant studies. 2017; 5(2):120-2.

8. Baig BA, Ramamoorthy D, Bhat TA, Threatened medicinal plants of Menwarsar Pahalgam, Kashmir Himalayas: Distribution pattern and current conservation status. Proceedings of the International Academy of Ecology and Environmental Sciences. 2013; 3(1):25.

9. Nasir E, Ali Sl. Flora of Pakistan. Berberidaceace. University of Karachi, Karachi. 1980-2005; 87: 1-31.

10. Tantry MA, Dar JA, Idris A, Akbar S, Shawl AS. Acylated flavonol glycosides from Epimedium elatum, a plant endemic to the Western Himalayas. Fitoterapia. 2012; 83(4):665-670.

11. Naseer S, Lone SH, Lone JA, Khuroo MA, Bhat KA. LC-MS guided isolation, quantification and antioxidant evaluation of bioactive principles from Epimedium elatum. Journal of Chromatography B. 2015; 989:62-70.

12. Arief ZM, Munshi AH, Shawl AS. Evaluation of medicinal value of Epimedium elatum on the basis of pharmacologically active constituents, Icariin and Icariside-II. Pakistan Journal of Pharmaceutical Sciences. 2015; 28(5). 
13. Arief ZM, Shawl AS, Munshi AH. Altitudinal variation in pharmacologically active compounds of wild and cultivated populations of Epimedium elatum. Journal of Applied Research on Medicinal and Aromatic Plants. 2016; 3(2):48-51.

14. Lone SA, Kushwaha M, Wani A, Kumar A, Gupta AP, Hassan QP, Gupta S. Genetic diversity, LCMS based chemical fingerprinting and antioxidant activity of Epimedium elatum Morr \& Decne. Journal of Applied Research on Medicinal and Aromatic Plants. 2017; 5:72-81.

15. Lone SA, Hassan QP, Gupta S, Mushtaq S, Sultan P, Bedi YS. Morphological studies and meiotic chromosome analysis of Epimedium elatum (Morr \& Decne)-Rare endemic medicinal plant of Northwestern Himalayas in India. Current Botany. 2017; 8.

16. Sofi SN, Shakeel-u-Rehman, Qazi PH, Lone SH, Bhat HM, Bhat KA. Isolation, identification, and simultaneous quantification of five major flavonoids in Epimedium elatum by high performance liquid chromatography. Journal of Liquid Chromatography \& Related Technologies. 2014; 37(8):1104-1113.

17. Dad JM, Khan AB. Threatened medicinal plants of Gurez valley, Kashmir Himalayas: distribution pattern and current conservation status. International Journal of Biodiversity Science, Ecosystem Services \& Management.2011; 7(1):20-26.

18. Ma H, He X, Yang Y, Li M, Hao D, Jia Z. The genus Epimedium: an ethnopharmacological and phytochemical review. Journal of Ethnopharmacology. 2011; 134(3):519-541.

19. Pharmacopoeia Commission of PR. China; In Pharmacopoeia of the People's Republic of China, (China Medico-Pharmaceutical Science \& Technology Publishing House), Beijing. 2010; Vol. I: 306.

20. Liu CR, Xu LX. Analysis of active ingredients of traditional Chinese herbal drug. Assay of icariin in Epimedium. Chinese Journal of Pharmaceutical Analysis. 1984; 4:81-84.

21. Xie PS, Yan YZ, Guo BL, Lam CWK, Chui SH, Yu QX. Chemical patternaided classification to simplify the intricacy of morphological taxonomy of Epimedium species using chromatographic fingerprinting. Journal of Pharmaceutical and Biomedical Analysis. 2010; 52(4):452-460.

22. Compilation $\mathrm{CH}$, China Herb Compilation. People's Medical Publishing House. 1975.

23. Malik AR, Siddique MAA, Sofi PA, Butola JS. Ethnomedicinal practices and conservation status of medicinal plants of North Kashmir Himalayas. Research Journal of Medicinal Plant. 2011; 5(5):515-530.

24. Quan QM, Fang ZL, Wu W, Li YX. Comparative analysis of morphological characteristics and effective composition content of wild and cultivated Epimedium pubescens and Epimedium wushanense (Berberidaceae). Journal of Medicinal Plants Research.
2011; 5(29):6523-6527.

25. Zhang Y, Dang H, Li S, Li J, Wang Y. Five new synonyms in Epimedium (Berberidaceae) from China. PhytoKeys. 2015; (49):1.

26. Liu S, Liu L, Huang $X, Z$ hu $Y, X u Y$. A taxonomic revision of three Chinese spurless species of genus Epimedium L.(Berberidaceae). PhytoKeys. 2017; (78): 23.

27. Zeng-li FAN. Research Advances in the Pharmacological Effects of Herba Epimedii. Journal of Anhui Agricultural Sciences. 2012; 17:029.

28. Zhang ML, Uhink $\mathrm{CH}$, Kadereit JW. Phylogeny and biogeography of Epimedium/Nancouveria (Berberidaceae): Western North AmericanEast Asian disjunctions, the origin of European mountain plant taxa, and East Asian species diversity. Systematic Botany. 2007; 32(1):81-92.

29. Rafiq RA. The flora of Palas valley and plant conservation priorities Report on the botanical studies in Palas valley (Report prepared for Himalayan Jungle Project, Palas Valley, Kohistan). 1995.

30. Jamal Z. Biodiversity, ethnobotany and conservation status of the flora of Kaghan Valley Mansehra, NWFP Pakistan. Ph.D thesis to Quaid-i-Azam University, Islamabad. 2009.

31. Jan S, Hamayun M, Khan SA, Ahmad N, Ahmad I, Wali S. Plant diversity of Hindu Kush mountain region of Utror and Gabral, Northern Pakistan. Pakistan Journal of Weed Science Research. 2015; 21(2): 247-271.

32. Kachroo $P$, Singh G. Forest flora of Srinagar and plants of neighbourhood. (Bishen Singh Mahendra Pal Singh, Dehradun, India). 1976.

33. Sharma BM, Jamwal PS. Flora of Upper Liddar Valleys of Kashmir Himalaya. (Scientific Publishers, Jodhpur, Rajasthan, India). 1998 Vol 2.

34. Samant SS. Conservation of rare endangered plants: The context of Nanda Devi Biosphere Reserve. Conservation and management of biological resources in Himalaya. In: Ramakrishnan P. S., Purohit A. N. Saxena K. G., Rao K. S. \& Maikhuri R. K. (eds). Conservation and Management of Biological Resources in Himalaya. (Oxford \& IBH Publishing Company, New Delhi). 1996; 521-545.

35. Dhar U. Conservation implications of plant endemism in high-altitude Himalaya. Current Science. 2002;141-148.

36. Alam J, Ali SI. Contribution to the Red List of the plants of Pakistan. Pakistan Journal of Botany. 2010; 42:2967-2971.

37. Cunningham WP, Saigo BW. Environmental Sciences: A Globa Concern. (The McGraw-Hill Companies, Boston). 1999.

38. Kala CP. Status and conservation of rare and endangered medicinal plants in the Indian Trans-Himalaya. Biol Cons. 2000; 93(3): 371-379. 